\title{
PARENT'S ENDOWMENT AND ACHIEVEMENT OF THEIR CHILDREN: A PRELIMINARY STUDY WITH HONG KONG DATA DURING ITS TRANSITION PERIODS
}

\section{CHEI WING YEE}

The Hong Kong Polytechnic University, Hong Kong Community College, Lecturer, Hong Kong

Since the mid-1990s there has been a striking increase in the propensity of youth to attend higher education. Lui (1997) argued that greater income dispersions within the group were found in group of workers with higher level of education and hence the Government's education policy should not be entirely blamed for the rise in income inequality. However, increasing cost of education might stop the children of lowest income deciles family from receiving further education and in turn deteriorates income inequality in Hong Kong.

In order to investigate the importance of parent's endowment on children's earnings in Hong Kong, the micro data of 1991, 1996 and 2001 census and by-censuses of Hong Kong would be used. As we look into the effects of parent's endowment on children's earnings, we would focus on families with children aged from 15 to 28 who live with their parents in this study.

During 1991 to 2001, Hong Kong experienced turned from economic peak to economic trough. Stimulated by the study of the effect of unemployment on income inequality during the time of economic recession (Mocan (1999), Johnson and Wilkins (2004)), we would first have a preliminary study on the distribution of children's activity status, educational attainment and employment status by their parent's income deciles. Then, we would look into the level of earnings and the income inequality of children. For the measurement of income inequality, the Gini coefficient is chosen as the primary measure of income inequality. In order to study the effect of family endowment on children's earnings, a simple OLS earnings regression analysis is used.

Our findings show that children in the lower income deciles family are more likely to be unemployed and are less likely to have senior posts during economic recession. However, there is no significant evidence to support that employed children in the higher income groups are with advantage in obtaining higher wages during economic expansion. Our regression result shows that the direct effect of family endowments on children's earnings and employment is positively significant but its effect is diminishing over time.

KEYWORDS: Earnings, Inequality, Employment \& Schooling
\end{abstract}

Received: Jun 20, 2017; Accepted: Jul 15, 2017; Published: Aug 04, 2017; Paper Id.: IJESRAUG201713

\section{INTRODUCTION}

\section{Background/ Objectives and Goals}

The official Gini coefficient in Hong Kong is among the most unequal in Asia and the Pacific which continuously increased from 0.45 to 0.54 during 1981 to 2011. Previous studies concentrated on analysis of income inequality being attributed to differences in their own personal endowment and their response to the market changes (Fan and Lui (2003), Lam and Liu (2011), Lui (1997), Sung, Zhang and Chan (2001)). Limited study has 
been done with the consideration of the effect of family endowment on income inequality in Hong Kong

Since the mid-1990s there has been a striking increase in the propensity of youth to attend higher education. Human capital theory suggests that educated workers receive higher wages than do uneducated workers, other factors being equal. Higher educated workers do have greater chances to be employed and promoted. Actually, upward social mobility is a key factor to be considered in analyzing changes in income inequality over time.

Lui (1997) argued that greater income dispersions within the group were found in group of workers with higher level of education and hence the Government's education policy should not be entirely blamed for the rise in income inequality. However, no one can deny that the government's education policy would affect the educational opportunities of various groups in the society differently. If it tends to favor the rich, its long-term effect on income inequality is enormous.

Johnson and Wilkins (2003), their study found that half of the increase in inequality was explained by changes in the distribution of employment. Gini coefficient increased by 0.122 due to labour force status changes in Australia. This implied that changes to the distribution of work in the population were an important source of growth in private income inequality.

Mocan (1999) indicated that sustained GNP growth was not a must for an improvement of income inequality. In the United States, an increase in structural unemployment was associated with an increase in the income share of the richest twenty percent of the population, and with a decrease in the shares of the bottom three quintiles. On the other hand, increase in cyclical unemployment was associated with a reduction in the income share of the second quintile.

During 1991 to 2001, Hong Kong turned from economic peak to economic trough. Besides, privatization of education system increased the cost of schooling. Is our tertiary education available to the youth from all income groups in Hong Kong? Do their employment status affected by their family endowment? With these challenges, we intend to provide some evidence to assess the effects of family endowments on the achievement of children's activity status, educational attainment, employment status and earnings.

\section{METHODS}

\section{Model and Data}

Stimulated by a natural approach to measure inequality of opportunity from Roemer's (1998) and a general functional form of "model of advantage" from Bourguignon et al (2007), we seek to identify the way family endowment acts on their children's achievement. Under their model, some personal characteristics are independent of the individual's will (circumstances) and "effort" made by the individual to increase his/her productivity and earnings. If the effect of this independent factor - parent's endowment is increasing in determining their children's achievement across the time, it would be crucial in affecting our intergeneration mobility and income inequality in long term.

In order to investigate the importance of parent's endowment on children's achievement in Hong Kong, the micro data of 1991, 1996 and 2001 census and by-censuses of Hong Kong would be used. As we look into the effects of parent's endowment on children's achievement, we would focus on families with 1) at least one parent work and with positive income and 2) with children aged from 15 to 28 who live with their parents in this paper. After creating the data sets, Table 1 shows the number of observations in our samples. 
Table 1: Number of Observations in the Samples

\begin{tabular}{|l|c|c|c|}
\hline \multicolumn{1}{|c|}{ Samples } & $\mathbf{1 9 9 1}$ & $\mathbf{1 9 9 6}$ & $\mathbf{2 0 0 1}$ \\
\hline All the youth live with their parents (ALL) & 48,344 & 52,164 & 56,745 \\
\hline The youth live with their parents and are in the labour force (LF) & 43,802 & 48,702 & 51,825 \\
\hline Young live with their parents and are being employed (EMP) & 25,389 & 25,356 & 26,243 \\
\hline
\end{tabular}

\section{Formula and Equation}

For the measurement of income inequality, the gini coefficient $(\mathrm{G})$ is chosen as the primary measure of income inequality For a population uniforms on the values $y_{i}$, where yi is the income of person $i$ and $i=1$ to $n$, we can calculate the Gini coefficient (G) with the following easy formula (Cowell, 1995):

$$
G=\frac{2 \sum_{i=1}^{n} i y_{i}}{n \sum_{i=1}^{n} y_{i}}-\frac{n+1}{n}
$$

where $\mathrm{i}=1, \ldots, \mathrm{n}$, indexed in no-decreasing order $\left(\mathrm{y}_{\mathrm{i}} \leq \mathrm{y}_{\mathrm{i}+1}\right)$.

In order to study the effect of family endowment on children's earnings, a simple OLS earnings regression analysis is used. The empirical strategy we adopt below is straightforward. The earnings regression with family endowments as independent variables in the model is used for gauging the effect of family endowment on children's achievement (Lam and Schoeni 1993). The following shows the regression model:

$$
\begin{aligned}
& \text { Ln MEARN = Intercept + MARR + WIDO + SCH + EXP +EXP }+ \text { Industrial dummies } \\
& + \text { Family endowment }(\mathrm{KSCH} \text { or KFAMY })
\end{aligned}
$$

Where In MEARN indicates children's log monthly income from main employment; MARR and WIDO is the dummy variables for marital status; SCH stands for the children's years of schooling; EXP is children's years of working experience; KSCH denotes the higher one of parent's years of schooling; KFAMY is the higher one of parent's log monthly income from main employment. As parent's monthly income is closely related to their educational level, to avoid multicollinearity problem, we run two regressions - one with $\mathrm{KSCH}$ only and the other with KFAMY only.

In this paper, we would first have a preliminary study on the activity status, educational attainment and occupational status of children with different family endowment. Then, we would look into the level of earnings and the earning inequality of children.

\section{RESULTS}

\section{Activity Status}

Business cycle might affect the achievement of youth differently because their parents would have different amount of resource to support their children. Table 2 shows the distribution of children's activity status by income deciles of their parents. It is now surprising that children in the higher income deciles are more likely to be a student because they are of higher educational attainment. However, they are more likely to be a student during economic recession but less likely to pursue study during economic growth. During 1991 to 1996, there was a 7.39\% reduction of their proportion as a student. On the other hand, the proportion of children to be a student in the lowest income group increased continuously from $11.88 \%$ to $14.47 \%$ from 1991 to 2001. It implies that children from all income groups are actually with more chance to further their study after the educational reform in Hong Kong. 
Unemployed workers are mainly found in the lower income deciles. The children from the $1^{\text {st }}$ and $2^{\text {nd }}$ income deciles account for about 50\% of unemployed in all years and its proportion was increasing during 1991 to 2001 . During economic recession in 2001, the $1^{\text {st }}$ and $2^{\text {nd }}$ income deciles groups account for $55 \%$ of discouraged workers.

Besides, children in the lower income deciles group are less likely to be an employer for all years. It is observed that they are lack of resources to start their own business when they are young. On the other hand, children with higher income parents are more able to start their own business. The children in the $5^{\text {th }}$ income decile account for $30.48 \%$ and $27.78 \%$ as an employer during economic boom in 1996 and economic recession in 2001 respectively.

Table 2: Distribution of Children's Activity Status by Income Deciles of Parents (In \%)

\begin{tabular}{|c|c|c|c|c|c|c|c|}
\hline $\mathbf{A L L}$ & $\begin{array}{l}\text { Income Deciles of } \\
\text { Parent* }\end{array}$ & Employee & Employer & Self-Employed & UE1** & UE2 & Student \\
\hline \multirow{6}{*}{1991} & 1 & 25.31 & 21.36 & 22.78 & 25.13 & - & 11.88 \\
\hline & 2 & 22.81 & 17.21 & 21.48 & 21.32 & - & 16.15 \\
\hline & 3 & 20.11 & 16.91 & 17.79 & 22.02 & - & 20.22 \\
\hline & 4 & 17.35 & 18.40 & 19.52 & 18.78 & - & 24.14 \\
\hline & 5 & 14.43 & 26.11 & 18.44 & 12.75 & - & 27.62 \\
\hline & Total & 100.0 & 100.0 & 100.0 & 100.0 & - & 100.0 \\
\hline \multirow{6}{*}{1996} & 1 & 25.48 & 18.15 & 22.58 & 24.06 & 24.85 & 13.48 \\
\hline & 2 & 21.80 & 17.47 & 22.12 & 23.28 & 25.73 & 17.65 \\
\hline & 3 & 19.51 & 14.73 & 16.59 & 21.52 & 18.71 & 20.57 \\
\hline & 4 & 17.74 & 19.18 & 20.74 & 18.13 & 20.18 & 22.73 \\
\hline & 5 & 15.47 & 30.48 & 17.97 & 13.01 & 10.53 & 25.58 \\
\hline & Total & 100.0 & 100.0 & 100.0 & 100.0 & 100.0 & 100.0 \\
\hline \multirow{6}{*}{2001} & 1 & 24.23 & 19.44 & 21.74 & 26.21 & 25.00 & 14.47 \\
\hline & 2 & 21.80 & 19.44 & 20.05 & 22.86 & 30.47 & 17.74 \\
\hline & 3 & 20.32 & 15.08 & 20.53 & 21.16 & 21.88 & 19.53 \\
\hline & 4 & 18.59 & 18.25 & 16.91 & 18.36 & 14.84 & 21.95 \\
\hline & 5 & 15.06 & 27.78 & 20.77 & 11.41 & 7.81 & 26.31 \\
\hline & Total & 100.0 & 100.0 & 100.0 & 100.0 & 100.0 & 100.0 \\
\hline
\end{tabular}

*For the income deciles groups - 1 indicates lowest income group and 5 indicates highest income group.

**UE1denotes all kinds of unemployment except discouraged unemployed (UE2) in 1996 and 2001.

\section{Educational Attainment}

Unlike most of the western developed countries, the education expenditure as percentage of GNP is quite low in Hong Kong during 1991-2001. Sustained economic development cannot be achieved without significant investments in human capital. Assuming abilities to be normally distributed, educational inequality might represent a loss in aggregate welfare. Thus, some researchers recognized this fact and started to analyze the distribution of education (Machin and Vignoles (2004)).

Table 3 reports the correlation of family endowment and children's years of schooling for those who are in the labor force. It shows a stronger correlation of children's schooling and parent's schooling over the time. On the other hand, the correlation of children's schooling and parent's earnings decreased from 1991 to 1996 and then increased afterward. It seems that the effect of family earnings on children's schooling becomes stronger after 1997. It is not surprising that children with parents in the lower income deciles are only with more resources to pursue higher education during economic boom than economic recession. Economic recession might force the children in the lower income family to give up their study to release some financial burden of their parents. 
Table 3: Correlation of Family Endowment and Children's Years of Schooling

\begin{tabular}{|l|c|c|c|}
\hline \multicolumn{1}{|c|}{$\mathbf{L F}$} & $\mathbf{1 9 9 1}$ & $\mathbf{1 9 9 6}$ & $\mathbf{2 0 0 1}$ \\
\hline Mother's years of schooling & 0.2248 & 0.2409 & 0.2892 \\
\hline & $(<.0001)$ & $(<.0001)$ & $(<.0001)$ \\
\hline Father's years of schooling & 0.2256 & 0.2355 & 0.2707 \\
\hline & $(<.0001)$ & $(<.0001)$ & $(<.0001)$ \\
\hline Parent's earnings (the higher one) & 0.19621 & 0.17885 & 0.23051 \\
\hline & $(<.0001)$ & $(<.0001)$ & $(<.0001)$ \\
\hline
\end{tabular}

Note: P-value in parentheses.

Change of educational policy from the emphasis of subsidized-mode to self-financed-mode scares the poor in achieving the higher education. In other words, the children of rich have more chances in achieving higher education with the opening of more privately-funded tertiary educational institutions. It implies that it is much difficult for the poor to get out of their current situation.

\section{Employment Status}

The situation of occupational segmentation is much serious during 1991 to 2001. Table 4 shows the distribution of children's occupational status by their family income deciles. The children in the lower income deciles group are mainly engaged in lower-level occupation, e.g. clerk, sales. Their proportion in the professionals and manager groups is relatively low in all years. Owing to the structural change of our economy, the proportion of children in the lowest income decile work as a clerk, craft and assemble worker also decreased significantly by $2.23 \%, 5.23 \%, 5.3 \%$ in 2001 respectively. Most of them worked as sales or elementary workers after 1997.

During economic expansion, the proportion of children in the lowest income decile to be professionals increased greatly by $10.9 \%$ from 1991 to 1996 . It seems that they still have chance to earn higher income if they can obtain professional qualifications.

However, it is clearly that there is a great reduction of proportion of children in the lowest income deciles to be manager in all years. During 1991-2001, their proportion to be manager decreased greatly by $19.5 \%$.

Table 4: Distribution of Children's Occupational Status by Income Deciles of Parents (In \%)

\begin{tabular}{|c|c|c|c|c|c|c|c|c|c|}
\hline EMP & $\begin{array}{c}\text { Income Deciles of } \\
\text { Parent }\end{array}$ & Manager & Prof. & $\begin{array}{l}\text { Asso. } \\
\text { Prof. }\end{array}$ & Clerk & Sales & Craft & Assem. & Elemen. \\
\hline \multirow{6}{*}{1991} & 1 & 18.75 & 17.97 & 21.56 & 23.26 & 23.85 & 30.59 & 34.18 & 32.30 \\
\hline & 2 & 12.15 & 16.02 & 21.64 & 22.28 & 23.02 & 24.14 & 26.67 & 25.08 \\
\hline & 3 & 18.58 & 19.14 & 17.95 & 20.44 & 21.13 & 20.19 & 18.25 & 20.02 \\
\hline & 4 & 15.45 & 17.32 & 17.84 & 18.66 & 18.37 & 15.92 & 14.06 & 13.75 \\
\hline & 5 & 35.07 & 29.56 & 21.01 & 15.36 & 13.63 & 9.15 & 6.83 & 8.85 \\
\hline & Total & 100.0 & 100.0 & 100.0 & 100.0 & 100.0 & 100.0 & 100.0 & 100.0 \\
\hline \multirow{6}{*}{1996} & 1 & 17.54 & 19.93 & 22.71 & 24.65 & 25.39 & 31.74 & 33.78 & 29.64 \\
\hline & 2 & 15.06 & 17.20 & 20.00 & 22.41 & 23.09 & 23.12 & 25.54 & 22.92 \\
\hline & 3 & 12.71 & 17.13 & 18.64 & 20.55 & 19.52 & 19.41 & 19.98 & 21.13 \\
\hline & 4 & 19.06 & 16.50 & 18.17 & 18.44 & 18.35 & 16.17 & 12.56 & 16.61 \\
\hline & 5 & 35.64 & 29.23 & 20.48 & 13.95 & 13.63 & 9.56 & 8.14 & 9.70 \\
\hline & Total & 100.0 & 100.0 & 100.0 & 100.0 & 100.0 & 100.0 & 100.0 & 100.0 \\
\hline \multirow{6}{*}{2001} & 1 & 15.14 & 17.56 & 20.88 & 24.10 & 27.44 & 30.08 & 31.99 & 30.43 \\
\hline & 2 & 15.94 & 16.79 & 20.05 & 23.10 & 22.67 & 23.24 & 22.85 & 24.61 \\
\hline & 3 & 16.53 & 16.22 & 19.32 & 21.02 & 20.49 & 21.75 & 23.12 & 20.52 \\
\hline & 4 & 16.53 & 18.58 & 19.15 & 19.56 & 17.54 & 16.89 & 14.38 & 16.07 \\
\hline & 5 & 35.86 & 30.84 & 20.59 & 12.22 & 11.86 & 8.03 & 7.66 & 8.36 \\
\hline & Total & 100.0 & 100.0 & 100.0 & 100.0 & 100.0 & 100.0 & 100.0 & 100.0 \\
\hline
\end{tabular}


To have more information on children's career development, Table 5 shows the distribution of children's industrial status by the income deciles of their parents. Children of lower income deciles group are mainly engage in manufacturing and wholesales industry while that of higher income deciles group are mainly engage in transportation, finance and communication industry.

Table 5: Distribution of Children's Industrial Status by Income Deciles of Parents (In \%)

\begin{tabular}{|c|c|c|c|c|c|c|c|}
\hline EMP & $\begin{array}{c}\text { Income Deciles of } \\
\text { Parent }\end{array}$ & Manufacturing & Wholesales & Transport & Finance & $\begin{array}{l}\text { Communi } \\
\text { cation }\end{array}$ & Others \\
\hline \multirow{6}{*}{1991} & 1 & 29.66 & 25.06 & 26.20 & 21.16 & 22.46 & 30.08 \\
\hline & 2 & 24.37 & 22.68 & 22.99 & 21.22 & 22.17 & 20.12 \\
\hline & 3 & 19.70 & 20.57 & 19.87 & 19.16 & 19.46 & 21.01 \\
\hline & 4 & 14.89 & 17.24 & 17.32 & 18.15 & 19.55 & 17.67 \\
\hline & 5 & 11.39 & 14.45 & 13.62 & 20.31 & 16.35 & 11.12 \\
\hline & Total & 100.0 & 100.0 & 100.0 & 100.0 & 100.0 & 100.0 \\
\hline \multirow{6}{*}{1996} & 1 & 28.60 & 25.46 & 26.89 & 22.09 & 23.48 & 15.22 \\
\hline & 2 & 23.09 & 23.12 & 22.66 & 20.11 & 20.18 & 18.26 \\
\hline & 3 & 18.91 & 19.02 & 20.14 & 20.15 & 20.22 & 20.38 \\
\hline & 4 & 15.89 & 17.85 & 17.34 & 17.71 & 19.03 & 22.17 \\
\hline & 5 & 13.51 & 14.55 & 12.97 & 19.94 & 17.10 & 23.97 \\
\hline & Total & 100.0 & 100.0 & 100.0 & 100.0 & 100.0 & 100.0 \\
\hline \multirow{6}{*}{2001} & 1 & 26.22 & 27.04 & 25.15 & 21.19 & 22.33 & 16.12 \\
\hline & 2 & 21.95 & 23.33 & 21.67 & 20.50 & 21.32 & 18.31 \\
\hline & 3 & 20.27 & 20.92 & 20.16 & 18.59 & 20.13 & 19.94 \\
\hline & 4 & 17.24 & 17.49 & 18.65 & 19.03 & 20.11 & 21.30 \\
\hline & 5 & 14.32 & 11.21 & 14.37 & 20.69 & 16.11 & 24.34 \\
\hline & Total & 100.0 & 100.0 & 100.0 & 100.0 & 100.0 & 100.0 \\
\hline
\end{tabular}

\section{Earnings}

Table 6 shows the mean earnings of children by their parents' income deciles. There is no key difference between their earnings level because children with higher income parent enjoy more years of schooling while children with lower income parent gain more years of experience. Thus, their earnings level is not significantly different without controlling other factors.

Table 6: The Mean Earnings of Children by Income Deciles of Parent (In Hong Kong Dollars)

\begin{tabular}{|c|c|c|c|c|c|c|c|c|c|c|}
\hline \multirow{2}{*}{19} & \multicolumn{2}{|c|}{1996} & \multicolumn{2}{c|}{2001} & \multicolumn{2}{c|}{ \% Change } & \multicolumn{2}{c|}{ \% Change } \\
\cline { 2 - 11 } & \multicolumn{2}{|c|}{1991} & \multicolumn{2}{|c|}{1996} & \multicolumn{2}{c|}{ 1996-2001 } \\
\cline { 2 - 11 } & Mearn & Lmearn & Mearn & Lmearn & Mearn & Lmearn & Mearn & Lmearn & Mearn & Lmearn \\
\hline 1 & 4692 & 8.11 & 9014 & 8.95 & 9246 & 8.99 & $92.09 \%$ & $10.25 \%$ & $2.57 \%$ & $0.46 \%$ \\
\hline 2 & 4812 & 8.17 & 8767 & 8.96 & 9364 & 9.00 & $82.20 \%$ & $9.74 \%$ & $6.81 \%$ & $0.45 \%$ \\
\hline 3 & 4920 & 8.23 & 9003 & 8.98 & 9420 & 9.01 & $82.96 \%$ & $9.15 \%$ & $4.63 \%$ & $0.33 \%$ \\
\hline 4 & 4961 & 8.16 & 9149 & 8.99 & 9560 & 9.02 & $84.40 \%$ & $10.14 \%$ & $4.49 \%$ & $0.34 \%$ \\
\hline 5 & 5931 & 8.32 & 11159 & 9.12 & 11577 & 9.15 & $88.14 \%$ & $9.52 \%$ & $3.74 \%$ & $0.35 \%$ \\
\hline
\end{tabular}

*Lmearn denotes the log monthly income of children from their main employment.

In order to study the direct effect of family endowment on children's earnings, a simple OLS earnings regression analysis is used. Table 7 shows the regression results of the effect of family endowment on children's earnings. It shows that the effect of parent's endowment on their children's earnings is positively significant after controlling the factors of individual endowment. The coefficient of KFAM and KSCH is positive and statistically significant. As the coefficient of KFAMY is greater than the coefficient of $\mathrm{KSCH}$, it implies that the major effect of family endowment on children's earnings is through parental income rather than parent's educational level. However, the direct effect of parental income on 
children's earnings is diminishing during 1991 to 2001.

Table 7: Regression Results of Family Endowment on Children's Earnings

\begin{tabular}{|c|c|c|c|c|c|c|c|c|c|c|c|c|}
\hline \multirow{3}{*}{\begin{tabular}{|c|} 
EMP \\
Variables \\
\end{tabular}} & \multicolumn{4}{|c|}{1991} & \multicolumn{4}{|c|}{1996} & \multicolumn{4}{|c|}{2001} \\
\hline & \multicolumn{2}{|c|}{ Regression 1} & \multicolumn{2}{|c|}{ Regression 2} & \multicolumn{2}{|c|}{ Regression 1} & \multicolumn{2}{|c|}{ Regression 2} & \multicolumn{2}{|c|}{ Regression 1} & \multicolumn{2}{|c|}{ Regression 2} \\
\hline & coef & t-stats & coef & t-stats & coef & t-stats & coef & t-stats & coef & t-stats & coef & t-stats \\
\hline Intercept & 6.174 & 107.070 & 5.220 & 37.800 & 7.371 & 276.970 & \begin{tabular}{|l|l|}
6.657 \\
\end{tabular} & 115.530 & 7.095 & 231.980 & 6.592 & 8.170 \\
\hline MARR & -0.003 & -0.060 & 0.000 & -0.010 & \begin{tabular}{|l|}
0.027 \\
\end{tabular} & 1.540 & .028 & 1.570 & 0.026 & 1.240 & 0.025 & .210 \\
\hline WID & -0.003 & 010 & $\mid-0.011$ & -0.050 & 0.100 & .180 & .112 & .330 & 0.144 & 2.010 & 0.147 & .050 \\
\hline $\mathrm{SCH}$ & 0.114 & .370 & 0.111 & 25.810 & 0.097 & 55.760 & \begin{tabular}{|l|}
0.096 \\
\end{tabular} & 5.940 & 0.109 & 57.880 & 0.108 & 58.450 \\
\hline EXP & 0.224 & 23.580 & 0.227 & 23.890 & 0.137 & 34.860 & 0.138 & 35.340 & 0.181 & 45.580 & 0.181 & 45.840 \\
\hline $\mathrm{EXP}^{2}$ & -0.012 & -15.750 & -0.012 & -15.860 & -0.007 & -22.130 & -0.007 & -22.160 & -0.009 & -27.870 & -0.009 & -27.920 \\
\hline Male & 0.0 & & \begin{tabular}{|l|}
0.015 \\
\end{tabular} & & \begin{tabular}{|l|}
0.009 \\
\end{tabular} & & \begin{tabular}{|l|}
0.010 \\
\end{tabular} & & 0.043 & 290 & 0.044 & 380 \\
\hline Whol & 0.0 & & 0.0 & & 0.0 & & 3 & & -0.033 & 310 & -0.032 & 230 \\
\hline Tran & 0.085 & 0 & \begin{tabular}{|l|}
0.078 \\
\end{tabular} & 30 & 0.046 & 20 & 0.044 & 0 & 0.040 & 350 & 0.038 & 240 \\
\hline Finan & 0.127 & 230 & 0.119 & 3.970 & .084 & 450 & \begin{tabular}{|l|}
0.079 \\
\end{tabular} & 10 & 0.070 & 580 & 0.068 & .460 \\
\hline Comm & 0.010 & 0.360 & 0.007 & 0.250 & \begin{tabular}{|l|}
0.069 \\
\end{tabular} & 5.510 & 0.066 & 5.270 & 0.000 & 0.030 & -0.001 & -0.040 \\
\hline Othind & -0.087 & -2.080 & -0.094 & -2.250 & 0.049 & 3.030 & 0.047 & 2.910 & 0.009 & 0.470 & 0.009 & 0.450 \\
\hline KSCH & 0.008 & 3.230 & & & 0.005 & 5.240 & & & 0.005 & 4.270 & & \\
\hline KFAN & & & 0.121 & & & & .084 & & & & 0.059 & 30 \\
\hline sqr & 501 & & 0.0620 & & & & 0.1598 & & 0.1920 & & 0.1944 & \\
\hline $1 \mathrm{D}$ & & & 0.0615 & & & & 0.1594 & & 0.1916 & & 0.1940 & \\
\hline & 25389 & & & & 25356 & & & & 26243 & & & \\
\hline
\end{tabular}

Note: The definition of marital status dummies and industry dummies follows that of Hong Kong census.

As we are interested in the achievement of children during different phases of business cycle, the Gini coefficient of youth earnings during 1991 to 2001 are shown in Table 8. The income inequality of youth in the employed group is much lower because of our sample selection that reduces the variation of their income.

Actually, the issue of income inequality is not restricted to economic causes. Almost all figures of Gini coefficient increase all the years. Except for the employed youth, the Gini coefficient increased by a greater percentage during economic expansion than economic recession. Consistent with sticky wage theory, wages are often said to be sticky-down although they can move up easily. Gini coefficient of employed youth decreases by 1.06\% during 1991-1996. Increases in wages of all groups might decrease the inequality index during economic expansion.

Table 8: Gini Coefficient of Children's Earnings

\begin{tabular}{|l|c|c|c|c|c|}
\hline & \multirow{2}{*}{$\mathbf{1 9 9 1}$} & $\mathbf{1 9 9 6}$ & \multirow{2}{*}{$\mathbf{2 0 0 1}$} & \% Change & \% Change \\
\cline { 5 - 6 } & & & & $\mathbf{1 9 9 1 - 1 9 9 6}$ & $\mathbf{1 9 9 6 - 2 0 0 1}$ \\
\hline ALL & 0.6030 & 0.6469 & 0.6665 & $7.27 \%$ & $3.03 \%$ \\
\hline LF & 0.5804 & 0.6218 & 0.6350 & $7.13 \%$ & $2.12 \%$ \\
\hline EMP & 0.2765 & 0.2736 & 0.2792 & $-1.06 \%$ & $2.03 \%$ \\
\hline
\end{tabular}

\section{CONCLUSIONS}

During economic recession, the proportion of children being unemployed for the lower income deciles groups increases while the proportion of discouraged unemployed worker for upper income deciles groups decreases significantly. Besides, children in the lower income families are with fewer resources to pursue study during economic recession. During all phases of business cycle, children in the higher income families are more likely to work in senior posts. However, there is no significant evidence to support that employed children in the higher income groups are with advantage in obtaining higher wages than others. There is a significant increase in proportion of children in the lower income groups to be 
professionals during economic expansion.

The regression result shows that the effect of parent's endowment on children's earnings is positively significant after controlling the factors of individual endowment. However, the major effect of parent's endowment on children's earnings is through parental income rather than their educational level. As its effect on children's earnings and employment is small and continuously diminishing during 1991-2001, we conclude that the effect of parent's endowment on children's earning through its indirect effect on schooling becomes more important in the future as cost of education is continuously rising for tertiary education.

\section{REFERENCES}

1. Bourguignon, François, Francisco H.G. Ferreira and Marta Menéndez (2007). Inequality of Opportunity in Brazil. Review of Income Wealth, 53 (4), 585-618.

2. Cowell, Frank A. (1995). Measuring Inequality, $2^{\text {nd }}$ ed., Prentice Hall Harvester Wheat sheaf.

3. Fan, C. Simon and Lui, Hon-kwong (June 2003). Structural change and the narrowing gender gap in wages: theory and evidence from Hong Kong. Labour Economics, 10, 609-629.

4. Johnson, D. and Wilkins, R. (2004 June). The Effects of Changes in Family Composition and Employment Patterns on the Distribution of Income in Australia: 1982-97-1998. Economic Record, 80(249), 219-238.

5. Lam, Kit-chun and Liu, Pak-wai (March 2011). Rising Earnings Inequality and Increasing Dispersion of Skills in Hong Kong. Journal of Comparative Economics, 39(1), 82-91.

6. Lui, H. K. (1997). Income Inequality and Economic Development. Hong Kong Economic Policy Studies Series, City University of Hong Kong Press.

7. Machin, S. and Vignoles, A. (2004). Educational inequality: the widening socio-economic gap. Fiscal Studies, 25, $107-128$.

8. Mocan, H. (1999). Structural employment, cyclical unemployment, and income inequality. The Review of Economics and Statistics, 81(1), 122-134.

9. Roemer, John E. (1998): Equality of Opportunity. Cambridge, MA: Harvard University Press.

10. Sung, Yun-wing, Zhang, Junsen and Chan, Chi-shing (2001). Gender Wage Differentials and Occupational Segregation in Hong Kong. 1981-1996, Pacific Economic Review, 6(3): 345-359.

11. The Hong Kong Council of Social Service (2014). Social Indicators of Hong Kong - Gini Coefficient. Retrieved from http://www.socialindicators.org.hk/en/indicators/economy/ 